\title{
Worrying trends
}

\section{The official 2008/09 South African crime statistics}

\section{JOHAN BURGER}

jburger@issafrica.org

The South African Police Service (SAPS) released the official crime statistics for 2008/2009 on 22 September 2009. As usual the statistics drew huge media and public interest. This article provides an overview of the key trends and offers an analysis of the statistics. Key trends include that the overall crime rate, after a five-year respite in which there was a downward trend, is on the increase; as are the so-called 'trio crimes' (house robberies, business robberies and car hijackings) and truck hijackings. This article briefly considers the controversy around the validity of the police's crime statistics and notes a few lessons from Colombia.

In spite of allegations, suspicion and, in some cases, evidence that the police manipulate the crime statistics, the annual release of the crime statistics by the South African Police Service (SAPS) continues to engender huge media and public interest. This is probably because it is the only official indication of how safe or unsafe we are. The figures recorded by the South African Banking Risk and Information Centre (SABRIC) and the Consumer Goods Council of South Africa (CGCSA) for crimes such as bank and cash-intransit robberies, ATM attacks and business robberies, allow us, in a limited number of cases, to verify the credibility of the police's crime figures. The results of the ISS victim survey (conducted every four to five years) are an additional source of data that allows for a comparison of the trends evident from the police statistics.

The 2008/9 crime statistics present a worrying trend. After five consecutive years of seeing a consistent decrease in the overall rate of crime, it appears that this year crime is again on the increase. As indicated by the graph in Figure 1, the rate of decrease, which started in 2003/04 (when our crime rate peaked), already showed signs of slowing down in 2006/07 and 2007/08. In the $2008 / 09$ reporting period the trend is clearly upward. The second major worry about the latest crime figures is the continued increase in the socalled trio crimes (house robberies, business robberies and car hijackings), and truck hijackings. For the first time also the first two of these trio crimes increased in all nine provinces, while car hijacking increased in seven provinces.

This article briefly considers the controversy around the validity of the police's crime statistics before discussing in more detail some of the worrying trends emerging from this year's crime report. ${ }^{1}$

\section{HOW CREDIBLE ARE THE SAPS CRIME STATISTICS?}

The short answer to this question is that we simply don't know. Over the past few months there were a number of media reports relating to allegations that the police are manipulating the crime 


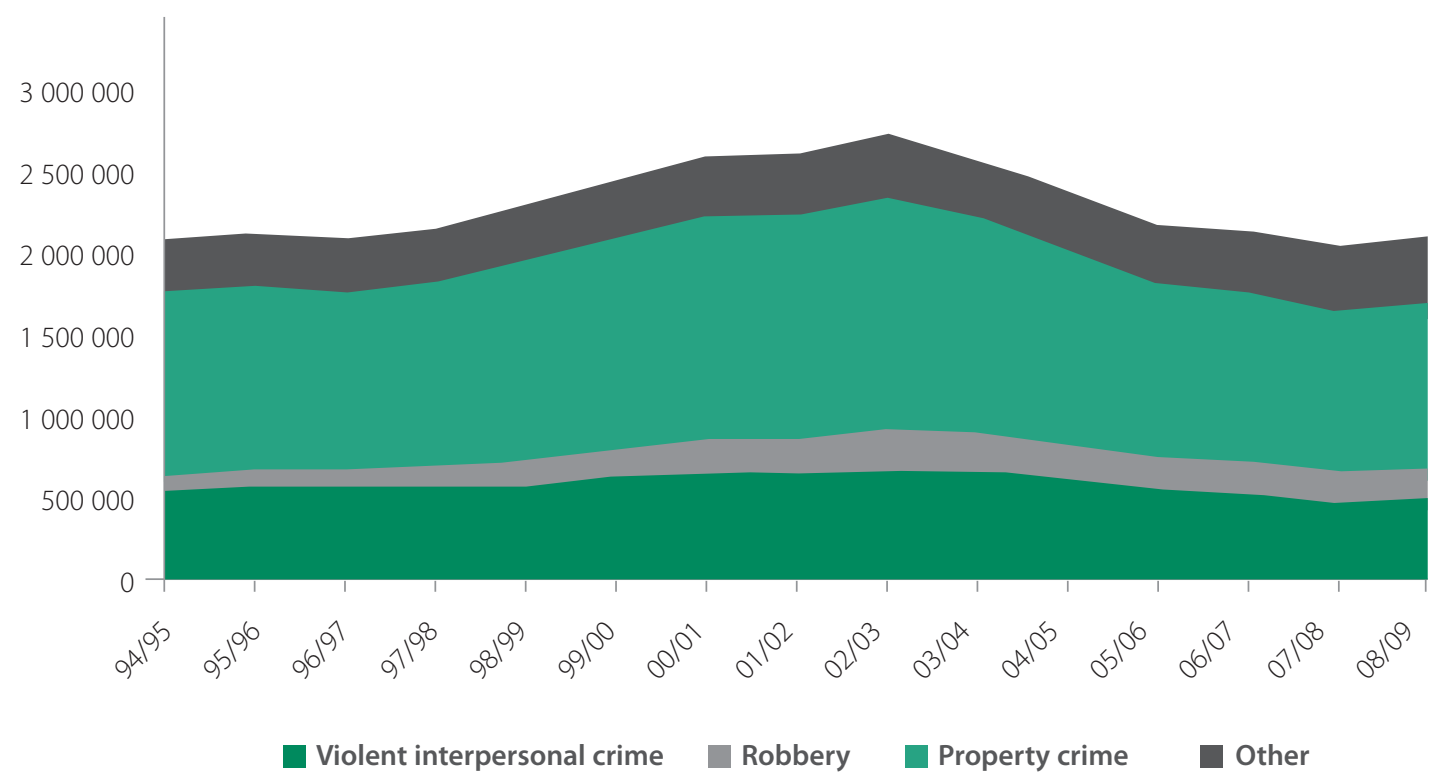

statistics. At least ten police stations were identified where crime statistics are not being recorded accurately: five in the Western Cape, four in Gauteng and one in KwaZulu-Natal. ${ }^{2}$ According to a report in the Cape Times, Lennit Max, MEC for Community Safety in the Western Cape, requested the Independent Complaints Directorate (ICD) to investigate allegations that crime statistics were being manipulated at Paarl, Paarl East, Mbekweni and Wellington police stations. ${ }^{3}$ He claims that according to his information, fifty-six rape cases reported at the Paarl police station over a two-year period had not been registered as criminal cases. At the Paarl East police station nineteen rape cases were allegedly reported and not registered; in Mbekweni sixteen rape cases; and in Wellington eight rape cases. In addition, according to Max, there are also allegations of serious crimes being registered as less serious offences at the Oudtshoorn police station. Serious allegations of manipulation were also made against the station commissioner of the Mountain Rise police station in KwaZulu-Natal. ${ }^{4}$

The ten or eleven police stations mentioned here make up less than one per cent of the 1116 police stations nationally, and the impact of manipulation at only these stations will have almost no impact on the national figures. But there are growing fears that the manipulation of crime statistics may be more widespread, even though there is no evidence to substantiate this. For the time being we have to accept the SAPS crime figures as at least fairly credible. However, there are other data that, at least to some extent, support the police's analysis of crime trends. In particular the data of SABRIC largely corroborate that of the SAPS for certain crime types.

\section{According to SABRIC's Annual Threat}

Assessment for 2009, bank robberies decreased by 16,8 per cent between 2007 and 2008 (SAPS - 29,2 per cent decrease); cash-in-transit robberies decreased by three per cent (SAPS - 2,3 per cent decrease); burglary increased by 35 per cent (SAPS figure for burglary at non-residential premises 11,1 per cent increase); and ATM attacks increased by 5,9 per cent (SAPS $-9,5$ per cent increase). ${ }^{5}$

The 2007 ISS Victim Survey, which showed a 12 per cent decrease in South Africa's overall crime rate since 1998, also provides some support for the SAPS statistics. ${ }^{6}$ The victim survey found that 22 per cent of respondents experienced a crime in the twelve months preceding the survey, compared to 25 per cent in 1998 , while 3,6 per cent indicated that they were victims of robbery, compared to 2,4 percent in 1998. The police's crime statistics show 


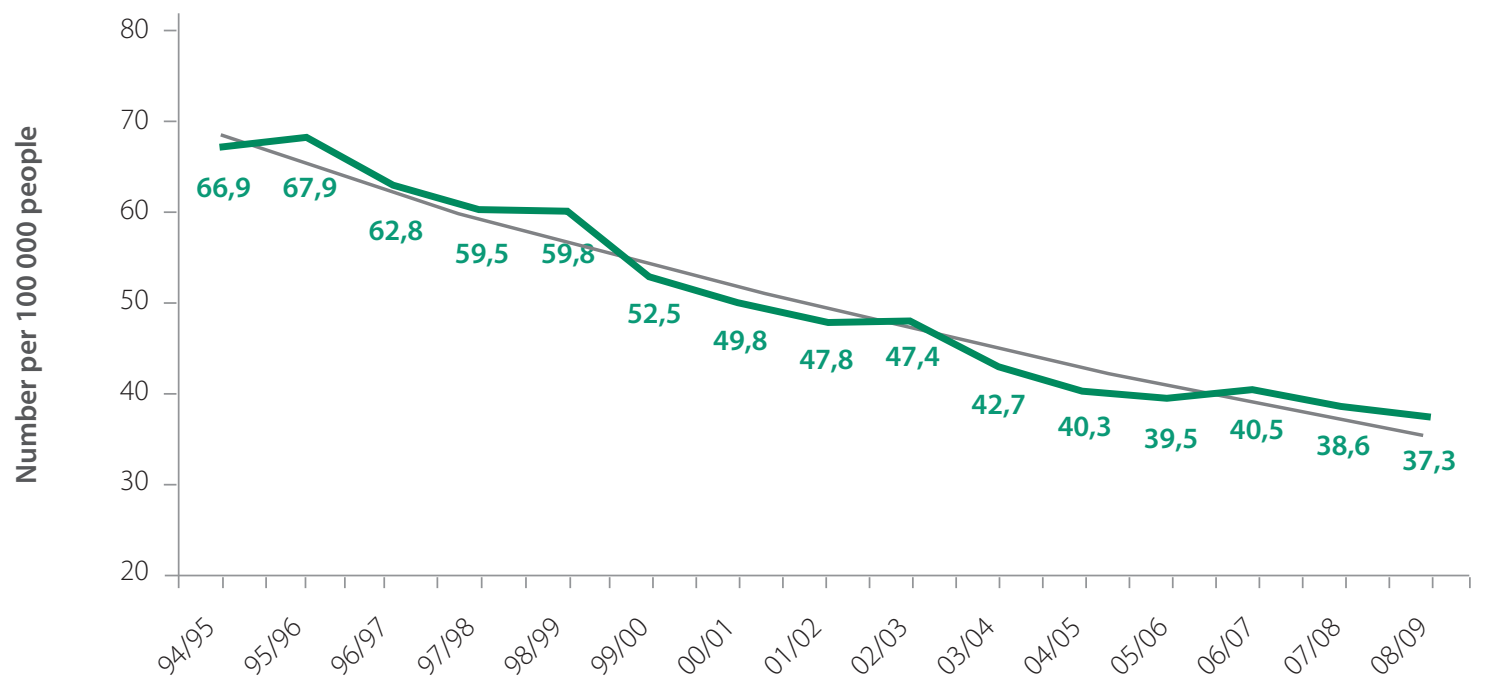

a decrease of approximately 24 per cent in the overall crime rate between 2002/03 and 2007/08 (Figure 1). The victim survey however showed that crime decreased at a lower rate (12 per cent) and over a longer period (since 1998) than the rate (24 per cent) indicated by the police's figures since 2002/03.

In summary, there clearly are some legitimate concerns about the credibility of the police's crime statistics, but overall the general trends indicated by these statistics are corroborated by independent data. This allows us, albeit with caution, to draw a few critical conclusions from the 2008/09 crime statistics and to determine what the most worrying trends are.

\section{THE WORRYING TRENDS IN THE 2008/09 CRIME STATISTICS ${ }^{7}$}

Although murder continues its downward trend of the last fourteen years (Figure 2), it remains a concern at 37,3 per hundred thousand, compared to the latest 'global homicide rate' estimated at 7,6 per hundred thousand. ${ }^{8}$ The most notable increases are in the aggravated robbery category and in particular in three of its seven subcategories, the so-called trio crimes (house robberies, business robberies and car hijackings).
The third worrying trend relates to increases in crimes targeting the business sector.

\section{Murder}

The good news about the murder rate is that it achieved an overall decrease of 44 per cent since it peaked at 67,9 per 100000 in 1995/96 (Figure 2). The current rate is 37,3 . In real figures this translates to 18148 murders; 1,8 per cent down from 18487 in the previous reporting period. The sad news is that at this rate it will take us at least another ten to twelve years to reach even the 'global homicide rate' of 7,6, unless we find a way to reduce crime, violent crime in particular.

Figure 3 provides the murder rate for twelve countries, including South Africa. ${ }^{9}$ There is, of course, a long list of countries with murder rates below one and two per 100 000, and probably a few with murder rates above or comparable to that of Honduras. But due to the unavailability, nonreporting or even non-existence of credible crime figures for all countries, it is impossible to determine precisely where South Africa would fit on a global scale for homicide or murder. It is encouraging to note that a country such as Colombia, that in 2000 had a murder rate of 62,7 , 


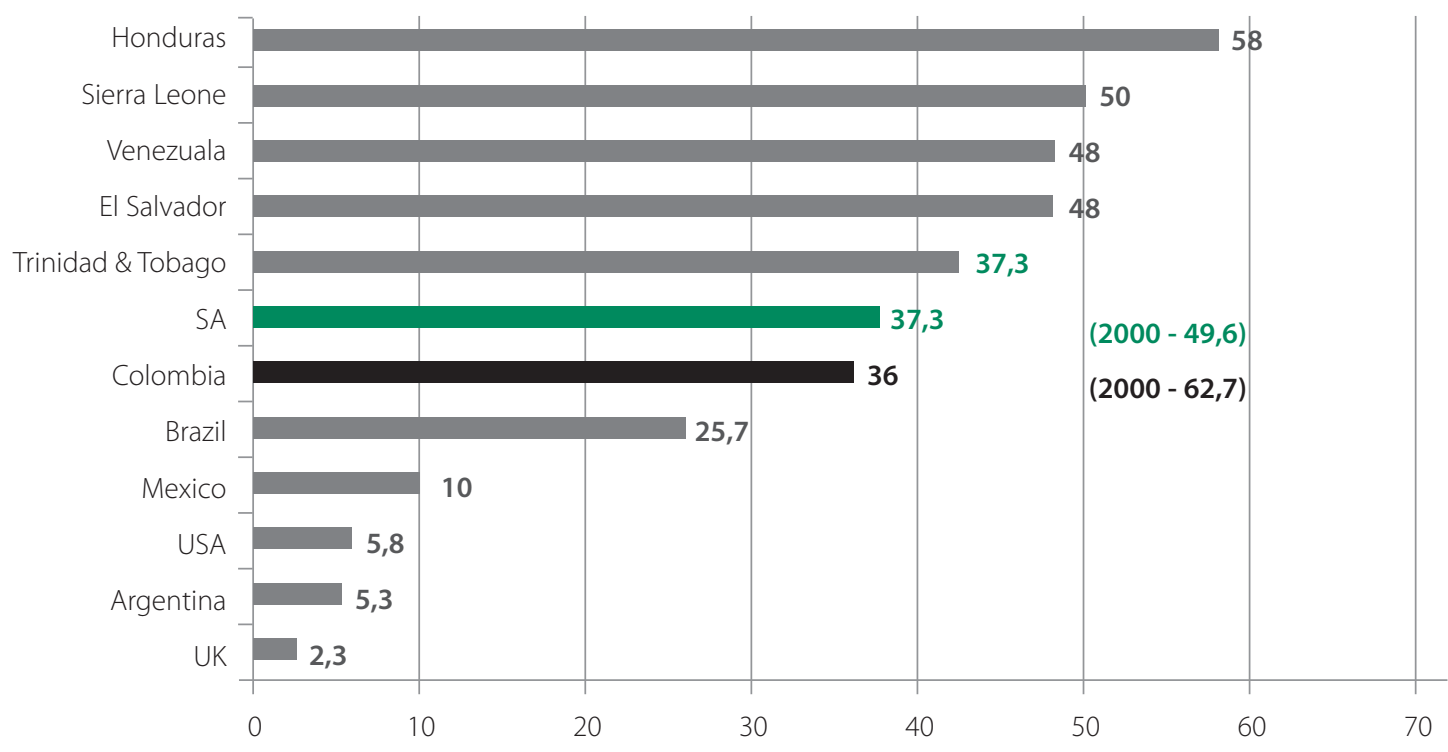

was able to bring that rate down by 43 per cent to 36 per 100000 within the relatively short space of eight years. By comparison, in 2000 South Africa's murder rate was 49,6 and during the same period we only managed to reduce our murder rate by 26 per cent. From these figures it is obvious that something positive is happening in Colombia that is worth looking at.

According to Mayra Buvinic, chief of the Social Program Division of the Inter-American Development Bank (IDB), Colombia's success is due to initiatives such as the Peaceful Coexistence and Citizen Security Program that was implemented in a number of Colombian cities, including Bogota, Cali and Medellin; and given financial assistance by the IDB. ${ }^{10}$ In these initiatives five key factors were crucial:

- Political commitment, especially in relation to the complex institutional and social changes that were required.

- Improving the performance and professionalism of the police. This was achieved inter alia through the allocation of more resources and improved training.

- Security was treated as only one component of a broad social strategy. Law enforcement of the 'crack-down' type had a limited effect and was rather designed to complement measures to improve public transport and road safety; to provide safe recreational areas; and to upgrade infrastructure and services in low-income neighbourhoods.

- In Bogota law enforcement agencies established better cooperation and coordination.

- Bogota also focused on community involvement such as the 'Frentes de Seguridad' (neighbourhood crime monitoring committees). This greatly enhanced the legitimacy of the police.

The Colombian focus on social and infrastructure development, and on improving service delivery in poor or low-income communities, should be considered against the background of service delivery protests in South Africa in the last few months. In a recent docket analysis by the SAPS, representing a sample of 1348 murder cases nationally for the period April 2007 to March 2008 , the impact of social behaviour on the prevalence of murder was confirmed. ${ }^{11}$ The analysis showed that almost two thirds (65,4 per cent) of these murders happened as a result of specific forms of social behaviour; 26,3 per cent was the result of criminal activities; 6,9 per cent was the result of group behaviour (vigilantism, gang activity or taxi violence); and 1,5 per cent was 


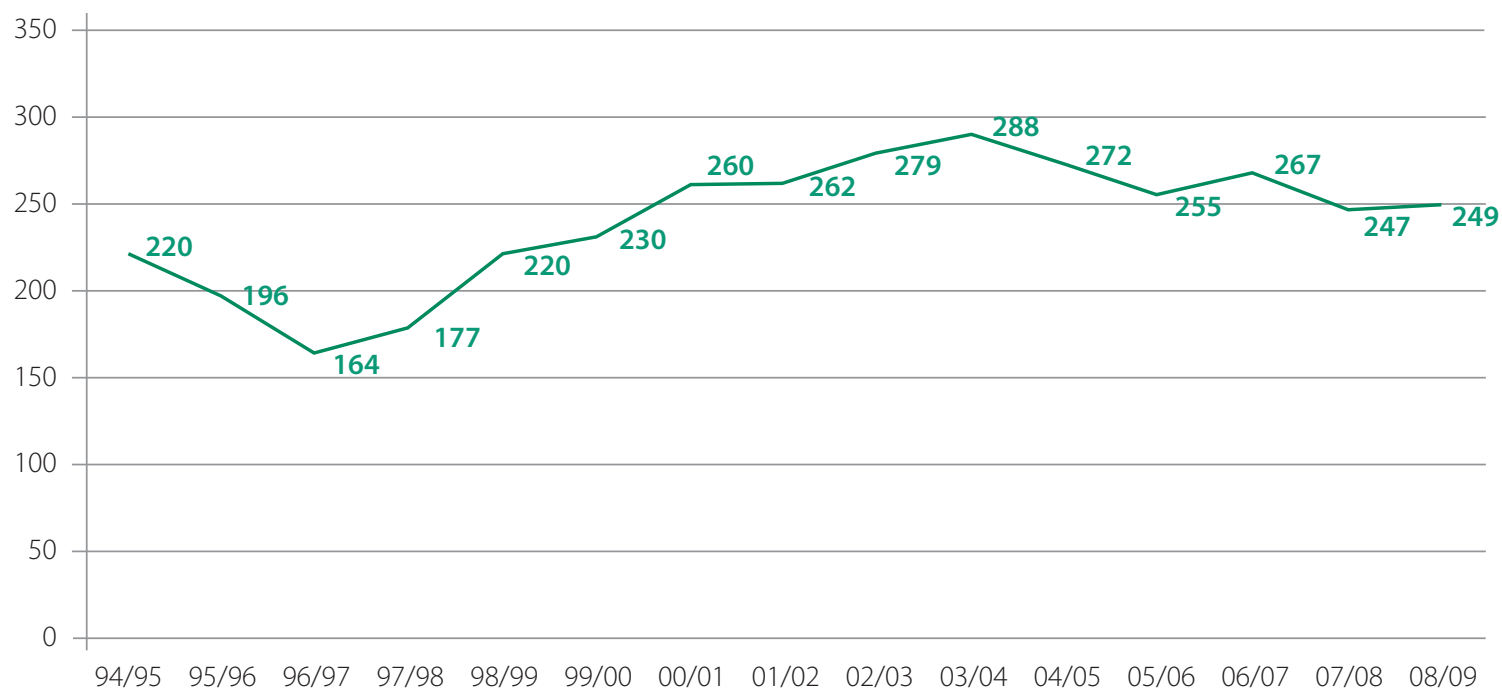

caused by accidental killings. A logical assumption would be that this is also true for various other violent crimes.

Violent crimes other than murder also decreased significantly. According to Gareth Newham, special projects manager in the Gauteng Department of Community Safety, violent crime in general in Bogota decreased by 75 per cent between 1996 and 2001. ${ }^{12}$ This was possible because of the reasons mentioned above, but also because of greatly improved crime intelligence that saw the arrest and detention rates of wanted criminals increase by 500 per cent.

\section{Aggravated robbery}

Unlike murder, and in spite of periodic and relatively small decreases, aggravated robbery remains at a level between 200-300 per 100000 (Figure 4). The current figure of 249,3 is up by 0,8 per cent from the $2007 / 08$ figure, after a decrease of 7,4 per cent the year before. As indicated in Figure 4, this is 52 per cent up from where we were (164) in 1996/97 when aggravated robbery was considered a major crime threat. This crime category comprises seven subcategories and it is in particular the trio crimes that cause the biggest concern. The other four sub-categories of aggravated robbery are street robbery (-7,4 per cent), cash-in-transit robbery (2,3 per cent), bank robbery (-29,2 per cent) and truck hijacking $(+15,4$ per cent $)$.

The trio crimes are currently South Africa's biggest crime threat and it is obvious that whatever we are doing to fight them is not working. This is not only a reflection of police performance, but the result of a combination of factors, including the performance of the criminal justice system and government in general.

The graph in Figure 5 clearly shows how all three the trio crime types have been increasing over the last number of years. The increases appear to be gaining momentum, probably because of the development of another extremely worrying trend. Both house robbery and business robbery have increased in all nine provinces, and car hijacking in seven provinces. In some provinces the increases are much faster than in others. Limpopo, for example, previously regarded as a stable province with relatively low levels of violent crime, now experiences some of the highest increases in trio crimes. Measured over a three-year period, from $2006 / 07$ to $2008 / 09$, the trio crimes in Limpopo and the Eastern Cape registered huge increases (Table 1). 


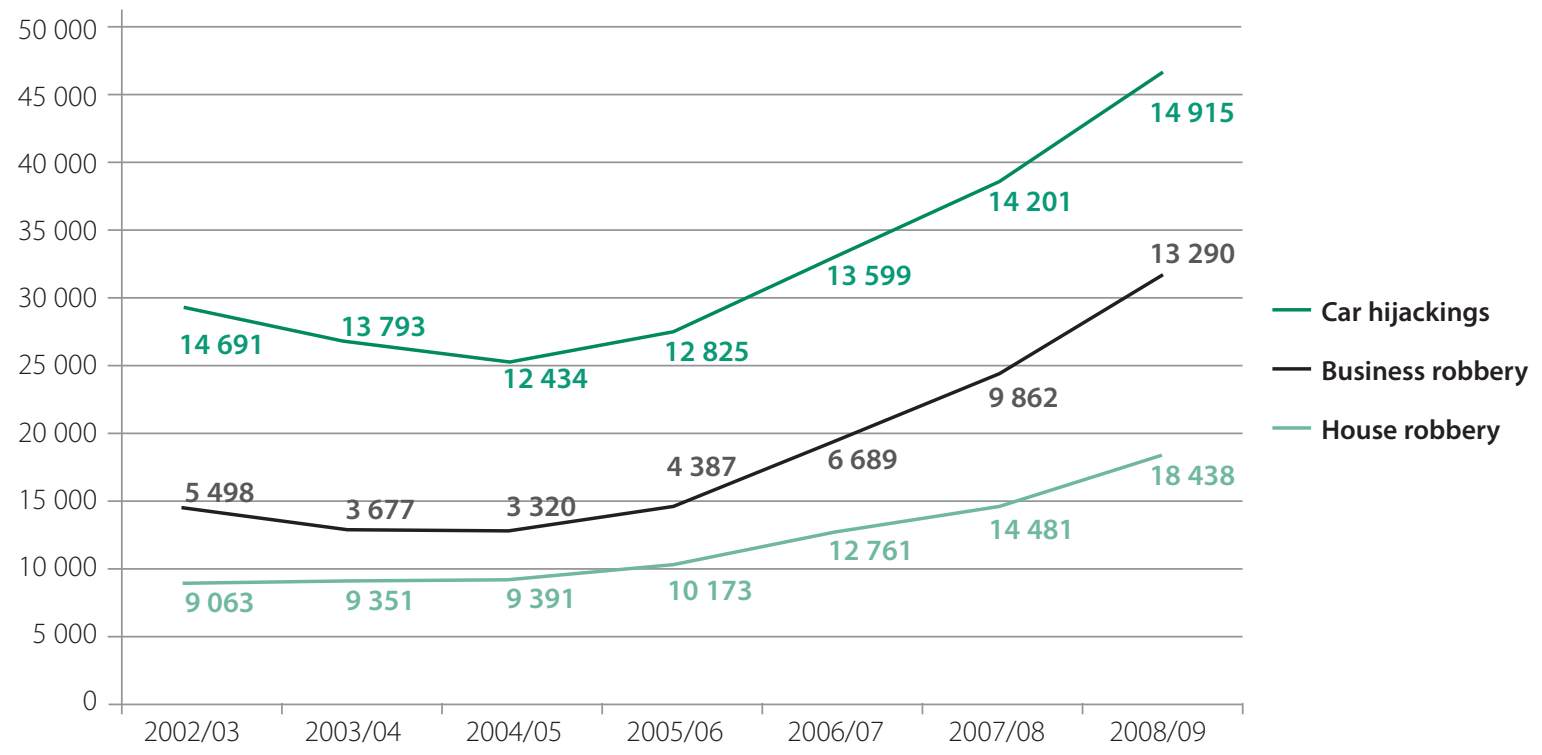

Although Gauteng continues to lead the other provinces with the highest incidence of trio crimes, there was also a marked reduction in the rate at which these crimes increased in that province. ${ }^{13}$ The increases in trio crimes in Gauteng over the last three years (2006/072008/09) are shown in Table 2.

After Gauteng, KwaZulu-Natal is the province with by far the highest incidence of trio crimes.

Table 1: Trio crimes in Limpopo and Eastern Cape

\begin{tabular}{l|c|c|c|c|}
\cline { 2 - 5 } & $\mathbf{2 0 0 6 / 0 7}$ & $\mathbf{2 0 0 8 / 0 9}$ & $\begin{array}{c}\% \\
\text { increase }\end{array}$ & $\begin{array}{c}\text { National } \\
\text { average } \\
\% \\
\text { increase }\end{array}$ \\
\hline $\begin{array}{l}\text { Limpopo } \\
\text { House } \\
\text { robberies }\end{array}$ & 162 & 514 & $217 \%$ & $44 \%$ \\
\hline $\begin{array}{l}\text { Business } \\
\text { robberies }\end{array}$ & 83 & 529 & $537 \%$ & $108 \%$ \\
\hline $\begin{array}{l}\text { Car } \\
\text { hijackings }\end{array}$ & 196 & 289 & $47 \%$ & $9 \%$ \\
\hline $\begin{array}{l}\text { Eastern } \\
\text { Cape } \\
\text { House } \\
\text { robberies }\end{array}$ & 344 & 1517 & $340 \%$ & $44 \%$ \\
\hline $\begin{array}{l}\text { Business } \\
\text { robberies }\end{array}$ & 241 & 851 & $253 \%$ & $108 \%$ \\
\hline $\begin{array}{l}\text { Car } \\
\text { hijackings }\end{array}$ & 607 & 706 & $16 \%$ & $9 \%$ \\
\hline
\end{tabular}

This province continues to show increases that are higher than the national average increase for these crimes (Table 2).

The three graphs in Figure 6 clearly show the enormity of the problem in relation to the trio crimes in Gauteng and KwaZulu-Natal, but it also shows that these crimes have increased in all the other provinces in the last financial year. The only exception is the decrease in car hijacking in the

Table 2: Trio crimes in Gauteng and KwaZulu-Natal

\begin{tabular}{l|c|c|c|c|}
\cline { 2 - 5 } & $\mathbf{2 0 0 6 / 0 7}$ & $\mathbf{2 0 0 8 / 0 9}$ & $\begin{array}{c}\% \\
\text { increase }\end{array}$ & $\begin{array}{c}\text { National } \\
\text { average } \\
\% \\
\text { increase }\end{array}$ \\
\hline $\begin{array}{l}\text { Gauteng } \\
\text { House } \\
\text { robberies }\end{array}$ & 7732 & 8122 & $5 \%$ & $44 \%$ \\
\hline $\begin{array}{l}\text { Business } \\
\text { robberies }\end{array}$ & 4492 & 6216 & $38 \%$ & $108 \%$ \\
\hline $\begin{array}{l}\text { Car } \\
\text { hijackings }\end{array}$ & 7314 & 7626 & $47 \%$ & $9 \%$ \\
\hline $\begin{array}{l}\text { Kwa-Zulu } \\
\text { Natal } \\
\text { House }\end{array}$ & 2667 & 4601 & $72 \%$ & $44 \%$ \\
\hline $\begin{array}{l}\text { robberies } \\
\begin{array}{l}\text { Business } \\
\text { robberies }\end{array}\end{array}$ & 997 & 2499 & $150 \%$ & $108 \%$ \\
\hline $\begin{array}{l}\text { Car } \\
\text { hijackings }\end{array}$ & 3563 & 4062 & $14 \%$ & $9 \%$ \\
\hline
\end{tabular}


Figure 6: Trio crimes per province
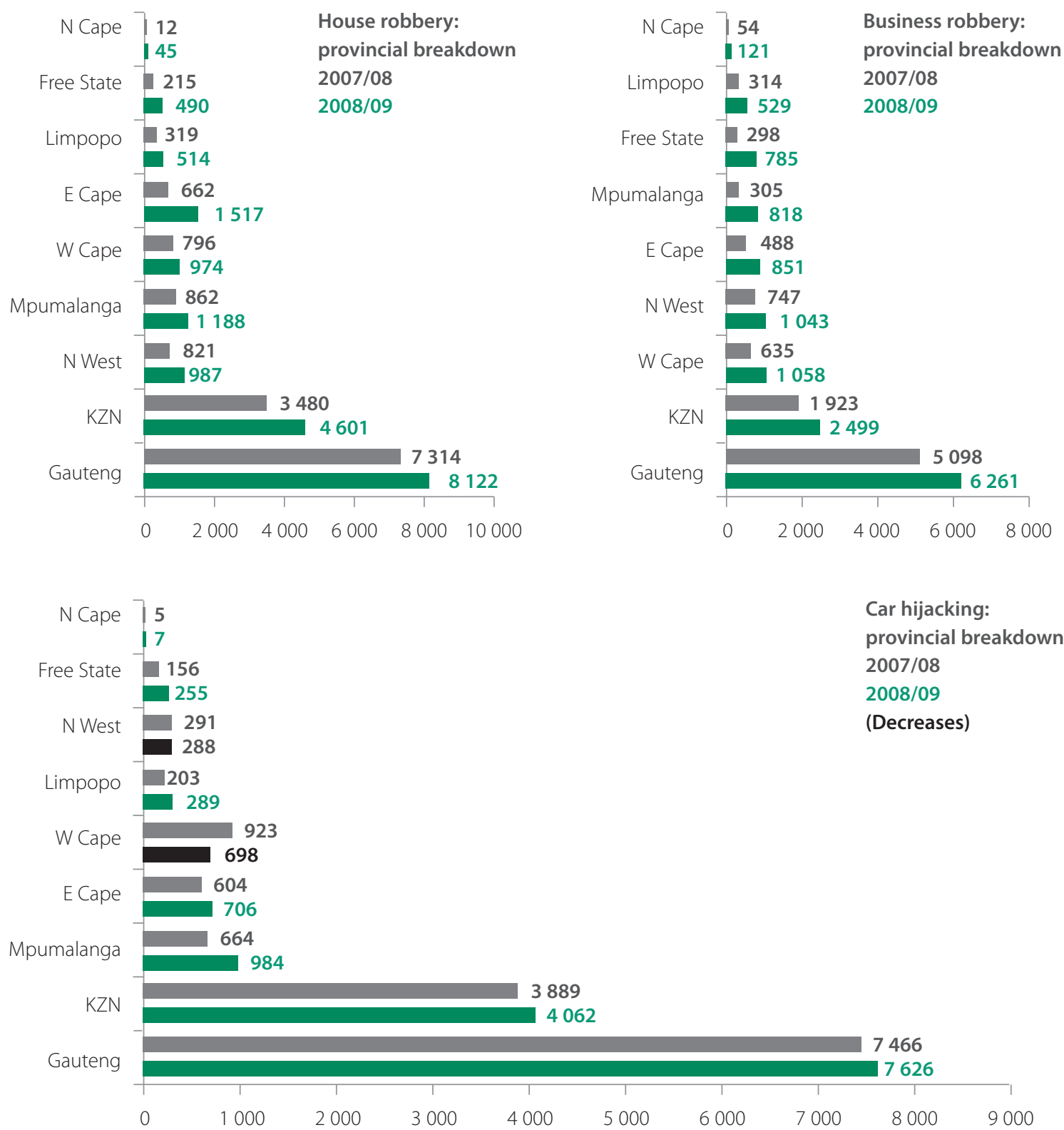

Western Cape (24,4 per cent) and North West (one per cent).

\section{Crimes against the business sector}

The two graphs in Figure 7 highlight four crimes that are clearly aimed at the business sector, and all four of these have been on the increase over the last four to five years. To this can be added burglary at non-residential premises (largely business premises).
Commercial crime has increased by 18,7 per cent in the last financial year and by 44 per cent since 2004/05. Shoplifting has increased by 20,6 per cent in the last financial year after remaining at more or less the same rate for the last four years. Burglary at non-residential premises increased by 11,1 per cent in $2008 / 09$ and by 25 per cent since 2004/05. In contrast, burglary at residential premises increased by 'only' 3,7 per cent in $2008 / 09$ and the overall rate since 2004/05 is down by more than ten per cent. 


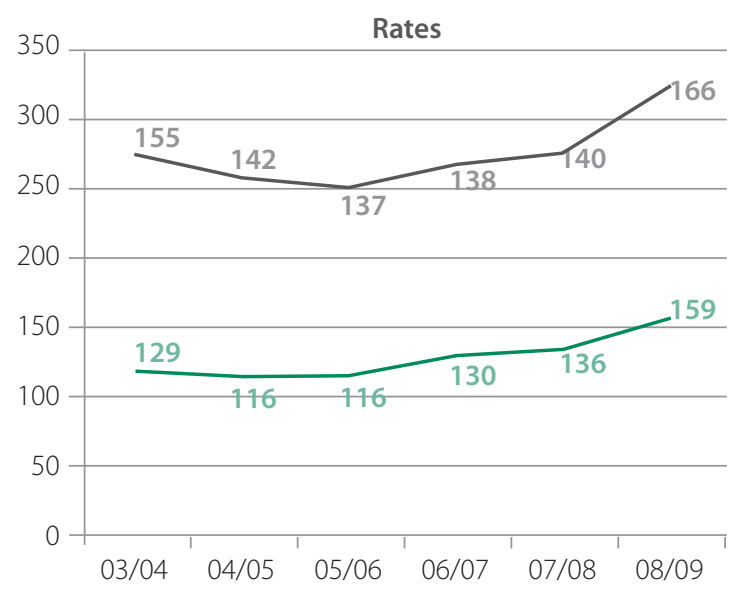

- Commercial crime - Shoplifting

As discussed above, business robberies are increasing at an even faster rate than house robberies. In the last financial year this crime type increased by 41,1 per cent and by 54 per cent since 2004/05. The hijacking of trucks, which has an obvious business connotation, increased at a faster rate than anything else. In the 2008/09 financial year truck hijackings increased by 15,4 per cent, and overall by 319 per cent since 2004/05.

It is perhaps too early to conclude that there is a correlation between the increased targeting of the business sector and the current economic recession, but there are a few indicators that appear to point in that direction. For example, in a September 2009 press release by the Consumer Goods Council of South Africa the following observation is made:

... in shoplifting the spread of incidents is much more even, reflecting the levels of poverty in Eastern and Northern Cape and other rural communities. This is coupled to a swing towards the shoplifting of food, which is indicative of the effects of the recession. ${ }^{14}$

In addition, Professor Haroon Bhorat, who teaches economics at the University of Cape Town, said in a briefing to Parliament on 25 September that South Africa was now the 'most unequal society in the world' with a significant increase in income

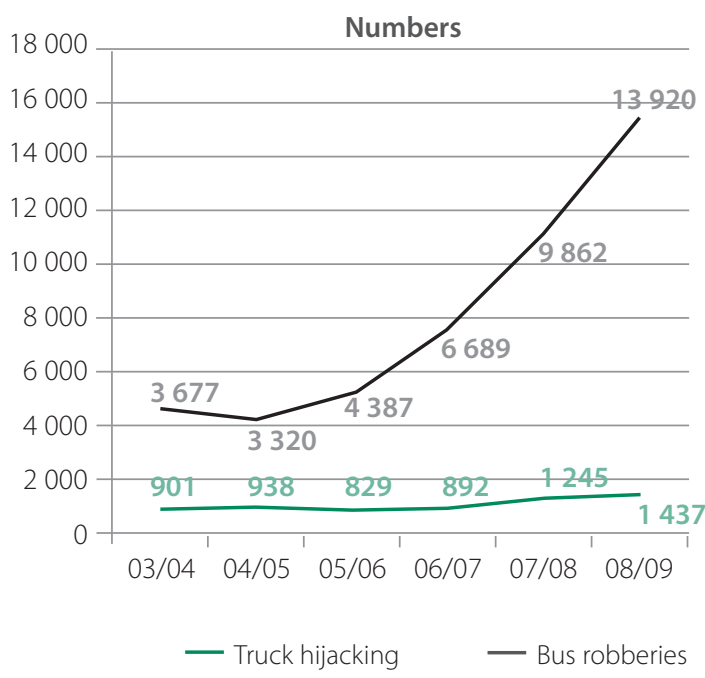

inequality. ${ }^{15}$ According to him this is, in the long run, bad for growth and a threat to social stability.

\section{CONCLUSION}

The above statistics and discussion presents us with four key messages:

- That sub-categories of violent crimes, and in particular aggravated robbery, of house and business robbery and car hijacking, are dangerously close to becoming out of control.

- That although the targeting of the business sector is not new, the increases in crimes relating to this sector are significantly higher than with other crimes, and have serious economic and social implications.

- That whatever we are doing to combat these crimes is not working.

- That building on the lessons from Colombia, the situation can be turned around if we have the will and if we understand that fixing the criminal justice system, and in particular the police, important as it is, is not enough.

What appears to be necessary is an integrated, overarching and well-coordinated approach that includes efforts to address the problems of the criminal justice system, while addressing inequality and other social problems. 
To comment on this article visit

http://www.issafrica.org/sacq.php

\section{NOTES}

1 The full crime report (crime statistics) of the South African Police Service (SAPS) is available at www.saps.gov.za. On the SAPS homepage, it can be accessed under documents or under publications and reports in the SAPS 2008/09 Annual Report. Power Point presentations on the crime statistics are also available on the ISS website at www.issafrica.org.

2 How cops fiddle crime statistics, Sunday Times, 4 July 2009.

3 Max attacks police boss, Cape Times, 24 June 2009.

4 Mountain Rise crime statistics questioned, The Witness, 23 September 2009.

5 SABRIC, Annual Threat Assessment 2009: An Overview of Developments during 2008 and Considerations for Future Prospects, March 2009, 29 30. The SAPS figures in brackets were inserted by the author from the SAPS Annual Report for 2008/09, available at: http://www.saps.gov.za, 5-6. (Accessed 15 October 2009). It must be pointed out that with burglary SABRIC only records incidents relating to bank property, whereas the SAPS records burglary of all non-residential property. That may also explain the big difference in the percentage increases. The SAPS figures for ATM attacks were provided by Director N Seimela in his presentation at an ISS seminar in Pretoria, 8 October 2009.

6 Antoinette Louw, Results of the 2007 national victim survey, presented at a seminar hosted by the Institute for Security Studies, Pretoria, 8 May 2008.

7 For purposes of this article the 10,1 per cent increase in the 'All sexual offences' category will not be discussed as a trend. This is a new crime category that replaces 'rape' and 'indecent assault' as a result of the implementation of the Criminal Law (Sexual Offences and Related Matters) Amendment Act, 2007 (Act No 32 of 2007). This Act created a number of new crimes and, unless these crimes can be disaggregated, comparisons with the period before December 2007 are nonsensical.

8 The estimated global homicide rate is included in a recent report by the Geneva Declaration on Armed Violence and Development and based on international homicide figures in 2004. Wikipedia, 'List of countries by intentional homicide'. Available at: http://en.wikipedia.org/wiki/List_of_countries_by_inte ntional_homicide. (Accessed 22 September 2009).

9 Ibid, 2-6.

10 M Buvinic, Against the odds, IDB America, 16 October 2009. Available at: <http://www.iadb.org $/$ idbamerica/index.cfm?thisid=2849>. (Accessed 16 October 2009).

11 South African Police Service, Annual Report 2008/2009, Head Office, Strategic Management, Pretoria, 2009, 10-11.

12 G Newham, presentation at an ISS seminar on the 2008/09 South African crime statistics, Pretoria, 8 October 2009. Also: South Africa: Country looks to Colombia to roll back crime, Business Day, 15 October 2009.
13 See Gareth Newham's article, The Gauteng Aggravated Robbery Strategy, in SA Crime Quarterly 29 (2009).

14 M Broughton, Director: Crime Prevention Programme and Shopping Centre Security Initiative of the Consumer Goods Council of South Africa, Press Release, 22 September 2009.

15 South Africa has widest gap between rich and poor: Study finds SA now falls below Brazil, Business Report, 28 September 2009. 